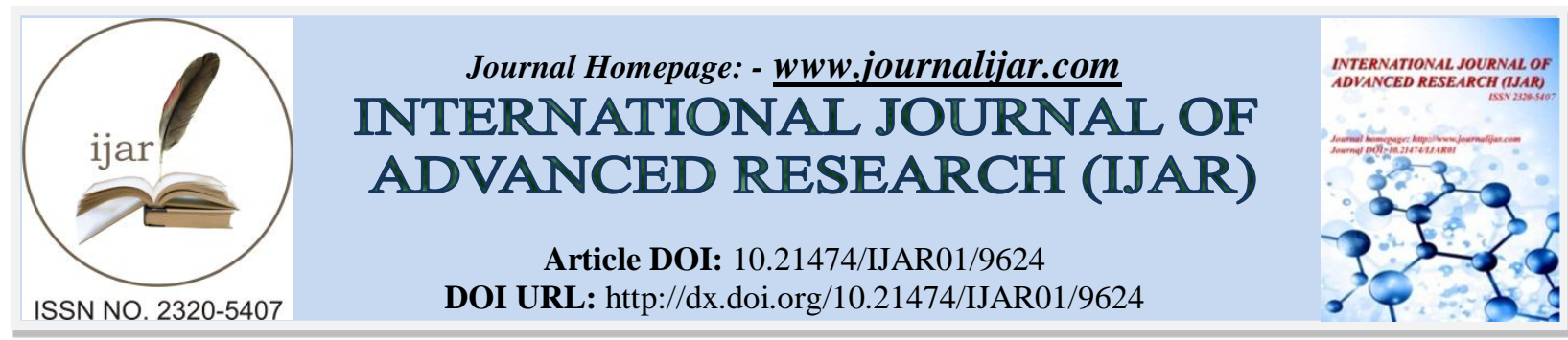

RESEARCH ARTICLE

\title{
ASSESSMENT OF FIXED ASSET ACQUISITION AND MANAGEMENT PRACTICE INGOVERNMENT SECTORS IN CASE OF DIRE WOREDA.
}

\author{
Abdi Aden Yasin ${ }^{1}$ and Doyo Borte ${ }^{2}$. \\ 1. Wolaita Sodo University, College of Business and Economics, Department of Public Administration and \\ Development Management, Wolaita Sodo and Postcode, 138, Ethiopia. \\ 2. Dire Woreda Finance and Economic Development Head.
}

\section{Manuscript Info}

Manuscript History

Received: 02 July 2019

Final Accepted: 04 August 2019

Published: September 2019

Key words:-

fixed asset, Disposal, fixed asset

planning, professional competency.

\begin{abstract}
The purpose of this research was to assess the practice of fixed asset acquisition and management in government sectors in case of Dire woreda. The study employed descriptive survey design and used both qualitative and quantitative data. The study used 20 sample which drawn from 67 total population using purposive sampling method. Data were collected through questionnaire from 18 employees and heads of government sectors. Two woreda officials who were delegated to work related to property administration were interviewed. Additionally, observation was used in data gathering. The collected data were systematically arranged, organized and analyzed using SPSS to generate descriptive statistics results presented in tables, frequency and percentage then thematically interpreted. The study revealed that lack of understanding and enforcing rules, regulations and directive, established system to enhancing understanding, handling and disposing fixed asset according to rules, regulations and directive, specifying fixed asset and lack of positioning sufficient and experienced professionals. The researcher recommended enhancing understanding of heads of public sectors as well as employees by establishing systems, maintaining accountability system in fixed asset acquisition and management, fully applying of rules, regulations and directive, establishment of modern property handling method and using professionals.
\end{abstract}

Copy Right, IJAR, 2019,. All rights reserved.

\section{Introduction:-}

Fixed assets are the focus of public asset management. Generally, asset management bears responsibility for every aspect of fixed assets, from planning and acquisition to disposition the property (Yoatai Lu, 2011). However, in accordance with Generally Accepted Accounting practice in Ireland (GAAP) and specifically FRS15 tangible fixed assets, tangible fixed assets are defined as an asset that have physical substance and are held for use in the production or supply of goods or services, for rental to others, or for administrative purposes on a continuing basis in the reporting entity's activities. This means that a fixed asset is an asset intended for continuing use, rather than a short term temporary assets such as stocks (UCC, 2012).

Corresponding Author:-Abdi Aden Yasin.

Address:-Wolaita Sodo University, College of Business and Economics, Department of Public Administration and Development Management, Wolaita Sodo and Postcode, 138, Ethiopia. 
Fixed assets are items of property that are tangible in nature; have significant value; have an economic useful life longer than one year; maintain their identities, either as separate entities or as identifiable components; are not repair parts or supply items; and are used in conduct of city activities (City of Houston Texas , 2005).

Ethiopian federal democratic republic government procurement and property administration proclamation number 649 / 2009 define a fixed assets as, tangible asset costing birr 1000 or more than is on operational use and that has a useful economic life or more than one year. Such as furniture, computers, heavy equipment, vehicles, ships and air craft, building roads, sewers, bridges, irrigations systems and dam. Like private business, a government should maximize the value of fixed assets when providing property services (Gold Hagen, 2007) cited in Yoatoi Lu (2011). However, traditional public asset management is still far from meeting these requirements (Kapanava McKellar \& Peterson, 2006) cited in Yaotai Lu (2011).Tag will be provided by the Finance office once the asset has been appropriately set up and recorded in the fixed asset register (UCC, 2012). Fixed asset are highly exposed to a mischief, fraud and theft because they have high market values so high controlling mechanisms are needed to safeguard them by preparing well designed manuals, polices, and procedures (Kikron et al, 2014). So, the researcher is initiated to assess the practice of fixed asset acquisition and management in Dire woreda public sectors to answer that the sectors were acquired and managed their fixed assets based on planned, economical and modern utilizations.

\section{Problem Statement}

Fixed assets are highly susceptible to depreciation, it is one thing to obtain an asset and another to utilized and maintain it meaningfully. It is usually disheartening to find properties of organization and government carelessly kept, abandoned or improperly utilized (Okoye, et al, 2009).

The absence and problem of asset management plan in public organization describe as the difficulty to determine what is needed in times of property asset, difficulty to determine what assets has the organization got, difficulty to determine what will close the gap, difficulty to determine how the organization will know it is getting there, difficulty to determining which asset should be a acquired, renewed, improved and maintained or disposed of (Getu, 2018).

According to MOFED (2007) government fixed asset management manual provides transitory procedure to attach the value of fixed asset in the accounts of public bodies .this requires much effort to be done on the valuation of fixed assets. Valuation of new assets is not a problem but valuation of assets that are in the use is not a simple task. One of the reasons for this is the need for expert knowledge to attach values to fixed assets. MOFED (2007), also state that the creation of professional team is very important if the process of attaching value for fixed assets and hence incorporation of the value of fixed assets in the financial ledger card is to be successful. This creates fertile ground for the future introductions of Accrual basis of Accounting.

As outlined in the government owned fixed asset management manual (2010), fixed asset management starts when fixed asset is issued from store. The acquisition of fixed assets in store is part of stock and should be managed by the stock management system. In addition to receiving of all types of property ,the stock management performs other activities; proper storage, issuance, recording, accounting and reporting, stock taking and stock control are part of the stock management activities which supplement the management of fixed asset.

According to MOFEC (2010) findings from the observation and interview of selected public bodies' stock management practice; there were no uniformity in the stock management activities, failure to comply with the existing property Administration directives and EFG accounting system with regarding to valuation and reporting to stocks ,tendency to consider the stock management activities as less important and relegated, consequently paying little attentions and personnel assignments to stock activities and huge amount of stock unused for many years in some public bodies that a wait action for disposal.

According to FDRE public procurement and property Administration agency survey research 2014/2015, of surveyed 52 government institutions 14(27\%) do not have material management plan, $37(71 \%)$ did not register their fixed assets on a fixed asset registration card, $16(81 \%)$ do not undertake annual inventory to control and manage their materials resources $18(34 \%)$ have not establish disposed materials price setting committee (FDRE public procurement and property Administration agency 2014/2015) as cited in Getu (2018). 
Fixed asset management in public sectors is one of the most challenging areas in many countries of the world. Businesses are cautious in managing their long-term assets properly and avoid unnecessary holding of these assets. Moreover, they record, depreciate, and dispose of the assets properly. However, this is not practical in public sectors. The problem is manifold in Ethiopia. Excessive holding, failing to value, depreciate, and dispose of the assets are the main challenges, and due to these challenges the loss resulting from mismanagement of the assets is substantial. Thus, it is advisable to invest properly in fixed assets and design appropriate management system which will help the government in reducing investment costs in long-term assets and ensuring proper utilization of public properties (Tadewos, 2012).

In line with the above stated problems Dire woreda is facing similar problems regarding fixed asset acquisition and management. The main problems observed by the researcher in the Woreda regarding fixed asset management are difficulty to plan, managing fixed assets according to rules and regulations, staffing fixed asset with sufficient professionals and generally, giving full attention to fixed asset management.

No research has addressed and forward the solution for the above problems in the government sectors specially at the Woreda level. This study aimed to assess the enforcement of law in public fixed asset acquisition and management, to assess fixed asset staff professional competency, to evaluate fixed asset planning in Dire Woreda public sectors and to contribute for efficiency and effectiveness of the system.

\section{Research Questions}

The researcher raised the following research questions.

1. What are the practices of regulation, rules, procedures and enforcement activities in fixed asset acquisition and management process?

2. What is the practice of planning process in fixed asset acquisition and management?

\section{Objective of the study \\ General Objective}

The general objective of the study is to assess the fixed asset acquisition and management practice in government sectors of Dire Woreda.

\section{Specific Objective}

The study had the following specific objectives.

1. To evaluate the practice of regulations, rules, directive and enforcement in fixed asset acquisition and management.

2. To evaluate the practice of planning, implementation process in fixed asset acquisition and management.

\section{Limitation of the Study}

The major limitation of this study was that the study assessed the practice of fixed asset acquisition and management by setting three specific objectives. These specific objectives were evaluating practice of rules, regulations and directive, evaluating practice of planning and to assess staff professional competency in Dire Woreda. Based on above specific objectives the researcher concludes his findings, but other researchers may reveal other findings by increasing the scope of study and setting additional objectives.

\section{Materials and Methods:- \\ The Study Area}

Mega is a town in southern Ethiopia. Located between Moyale and Yabelo on the paved highway south to Kenya, in the Borena Zone of the Oromia Region (or kilil), this town has a latitude and longitude of $4^{\circ} 01^{\prime} \mathrm{N} 38^{\circ} 15^{\prime} \mathrm{E}$ with an elevation of 1740 meters above sea level. Named for a nearby mountain, this town is the administrative center of Dire woreda. This town is reported to have telephone service and a post office, as well as at least one primary and one secondary school and financial institutions.

\section{Study Design}

The descriptive survey approach used in this study to describe records, analyses and interpret the nature the problem under investigation based on the opinions of the respondents using this approach; the researcher assessed the practice of enforcement of law through public fixed asset acquisition and management, planning and implementation 
of public fixed asset acquisition and management and staff professional competency to achieve organization objectives.

\section{Types and Source of Data}

Data was collected from different sources that have direct and/or indirect linkage with public fixed asset acquisition and management system. Primary sources were used to investigate the issue. As primary source the Dire woreda finance and economic cooperation office staff members and Dire woreda poverty reduction sectors (i.e. Woreda health office, education office, water, mineral and energy office, pastoralist development office and Road Authority office) heads were included through the questionnaire. Findings from interviews and observation of sectors fixed asset acquisition and management practices also considered as source of data.

\section{Sample size and Sampling technique}

Since the purpose of this study is to assess practices of fixed asset acquisition and management, the target population of this study included Dire Woreda Finance and Economic cooperation office staff members, heads of woreda's sectors are indirectly involved in fixed asset acquisition and management system and familiar with the practice of the subject under the study and considered as key informants. Along these lines, the total target population taken was 67 and from the population a valid sample size was selected. The study generalized to Dire woreda government sectors. For this descriptive research, Judgmental sampling technique applied to select representative samples from the target population.

Respondents from staff of Dire finance and economic cooperation office (WOFECO) as well as selected heads of government sectors selected based on the varieties of their experience, duties and responsibility toward the subject. From judgmental selected respondents the first 18 respondents were participating through the questionnaires while the remaining 2 respondents were participated in the interviews. The two interview participants were: 1(one Head of WOFECO, 1(one) Head of Dire Woreda Administration office who has general knowledge on the topic.

\section{Techniques and Tools of data collection}

The researcher utilized triangulation in data gathering process for this descriptive survey. According to john, et al, (2007) a need for triangulation is in order to search both accuracy of the data and alternate explanations. The idea is to collect data by different means and the hope is that there convergence on the truth. Therefore, questionnaires, interview and observation were used as tools during data collection.

\section{Data Analysis Tools}

The analysis and interpretation of the collected data carried out according to their type and nature by relating to basic questions of the study. First, the collected raw data through questionnaire, interview, and personal observation organized in to a form that can give meaning, and then structured and analyzed using simple mathematical applications of descriptive statistics, figures, percentage and frequency employing using SPSS version 20 soft ware and intensively described in the statements. Moreover, the qualitative data was analyzed and interpreted by relating and triangulating with quantitative data findings. This was employed to ascertain content validity of the data.

\section{Ethical Consideration}

Before conducting interviews I had to seek consent from the participants by telling them what the study was all about. However participation to this study was optional no one was forced to take part. Respondents were free not to answer the questions that they were not comfortable with. I managed to maintain anonymity and confidentiality of the respondents and the recorded data. No participants name or physical address was recorded. This holped to link anyone information with their identities. Confidentiality of respondents and information were also maintained. I tried to prevent access of information to the people who are not part of this study

\section{Data Analysis, Results and Discussion:-}

This chapter analysis results and discusses of the research based on the survey conducted in the study area. It presents using tables and percentages to Assess fixed asset acquisition and management practice in the study area. Data collection work was conducted and administrated by the researcher as the result there was no any non responded questionnaires. From 18 judgmentally sampled representative respondents 18 (100\%) have responded the questionnaires critically with necessary information. 
As well as interview was made with two planned officials. Hence the paper analyzed data from all respondents in the study area using SPSS version 20 using descriptive techniques such as percentage and frequency.

Enforcement of fixed asset acquisition and management regulation, proclamation and directives

Table 4.1:-Awareness and understanding of respondents on fixed asset acquisition and management rules and regulations

\begin{tabular}{|c|c|c|c|c|c|c|c|c|}
\hline \multirow[t]{2}{*}{$\mathbf{N}$} & \multirow[t]{2}{*}{ Items } & \multirow[t]{2}{*}{ response } & \multicolumn{5}{|c|}{ Rating scale } & \multirow[t]{2}{*}{ Total } \\
\hline & & & SA & A & $\mathrm{N}$ & DA & SD & \\
\hline \multirow[t]{2}{*}{1} & \multirow{2}{*}{$\begin{array}{l}\text { As a member of Dire woreda employee and } \\
\text { leadership, I have understanding of fixed asset } \\
\text { acquisition and Management rule and regulation }\end{array}$} & $\mathbf{F}$ & 3 & 5 & 1 & 7 & 2 & 18 \\
\hline & & $\%$ & 16.7 & 27.8 & 5.6 & 38.9 & 11.1 & 100 \\
\hline \multirow[t]{2}{*}{2} & \multirow{2}{*}{$\begin{array}{l}\text { As a member of Dire woreda employee and } \\
\text { leadership, I have understanding of fixed asset } \\
\text { acquisition and management directives }\end{array}$} & $\mathbf{F}$ & 0 & 7 & 0 & 11 & 0 & 18 \\
\hline & & $\%$ & 0 & 38.9 & 0 & 61.1 & 0 & 100 \\
\hline \multirow[t]{2}{*}{3} & \multirow{2}{*}{$\begin{array}{l}\text { There is established System to increase Dire Woreda } \\
\text { employee and heads of sectors understanding of } \\
\text { rules, regulations and directives of fixed asset } \\
\text { acquisition and management }\end{array}$} & $\mathbf{F}$ & 0 & 3 & 0 & 12 & 3 & 18 \\
\hline & & $\%$ & 0 & 16.7 & 0 & 66.7 & 16.7 & 100 \\
\hline
\end{tabular}

Source: field survey 2019.

Regarding above table item 1, concerning understanding of respondents on rules and regulations of fixed asset acquisition and management $9(50 \%)$ revealed as disagree and strongly disagree, $8(44.5 \%)$ answered agree and strongly agree and $1(5.6 \%)$ responded undecided. This indicated that half of respondents had not understanding of rules and regulations. As shown on the above table item 2 regarding to understanding of respondents on directives of fixed asset acquisition and management 11(61.1\%) answered disagree and 7(38.9\%) of them answered agree.

These shows majority of respondents are still having not understanding on directives too. This indicates that both employees and heads of public sectors were managing fixed asset without necessary knowledge of rule, regulations and directives.

On table 4.1 last item $15(83.4 \%)$ respondents answered disagree and strongly disagree while $3(16.7 \%)$ of them responded agree. It implies that there were no established system to increase understanding of woreda's employees and heads of sectors regarding rules, regulations and directives of fixed asset acquisition and management. The above findings are supported by empirical studies in our country. Getu (2018) reveals that for the problem arising and wrong attitude for property handling and care comes from poor understanding of property administration rule, regulations and directive. The study made by Mata (2015) also reveals that there is a significant knowledge and skill gap in Addis Ababa sub cities in property management policies and procedures.

Interview made with Dire Woreda finance and economic cooperation office head reveals that regarding establishing system to increase understanding of employees and heads of sectors, there was no established system at woreda level to boost understanding of employees and heads of woreda sectors on rule, regulations and Directive of fixed asset acquisition and management except few trainings organized by regional government for employees working on property administration.

\begin{tabular}{|c|c|c|c|c|c|c|c|c|}
\hline \multirow[t]{2}{*}{ No } & \multirow[t]{2}{*}{ Items } & \multirow[t]{2}{*}{ Response } & \multicolumn{6}{|c|}{ Rating scale } \\
\hline & & & SA & $\mathrm{A}$ & $\mathrm{N}$ & DA & SD & Total \\
\hline \multirow[t]{2}{*}{1} & \multirow{2}{*}{$\begin{array}{l}\text { Accountability would be applied in the case } \\
\text { of lose and damage on fixed asset happened } \\
\text { by the negligence of individual. }\end{array}$} & $\mathbf{F}$ & 1 & 3 & 2 & 9 & 3 & 18 \\
\hline & & $\%$ & 5.6 & 16.7 & 11.1 & 50 & 16.7 & 100 \\
\hline \multirow[t]{2}{*}{2} & \multirow{2}{*}{$\begin{array}{l}\text { Property Disposal committee is assigned and } \\
\text { Performs according to directive }\end{array}$} & $\mathbf{F}$ & 1 & 3 & 2 & 11 & 1 & 18 \\
\hline & & $\%$ & 5.6 & 16.7 & 11.1 & 61.1 & 5.6 & 100 \\
\hline \multirow[b]{2}{*}{3} & \multirow{2}{*}{$\begin{array}{l}\text { Fixed asset acquisition and management process } \\
\text { is performed according to rules, regulations and } \\
\text { directive }\end{array}$} & $\mathbf{F}$ & 0 & 3 & 1 & 12 & 2 & 18 \\
\hline & & $\%$ & 0 & 16.7 & 5.6 & 66.7 & 11.1 & 100 \\
\hline
\end{tabular}

Table 4.2:-Enforcement of rule, regulations and directives of fixed asset acquisition and management 


\section{Source: field survey 2019}

From above table item 1 regarding to the application of accountability in case of lose and damage on fixed asset happened by negligence of individual $12(66.7 \%)$ respondents answered disagree and strongly disagree. $4(22.3 \%)$ respondents answered agree and strongly agree while $2(11.1 \%)$ respondents responded neutral. From the above data majority of respondents agree that no accountability is applied in case of lose and damage on fixed asset happened by the negligence of individuals. This indicates that accountability system is not maintained in woreda regarding fixed asset acquisition and management in case of loses and damage happened by negligence of individuals. On the other hand interview made by Dire woreda finance and economic cooperation office head and head of woreda administration office confirm this.

They said that even if some measures were taken by woreda in case of damage and lose of property by individuals there is weakness in fully applying accountability. The observation result proved from damaged and stored property in every sectors compound including on employee's hand the reality of less action according to rule and regulations. From the some table item 2 regarding to assigning property disposal committee and performing according to rule and regulations 12(66.7\%) respondents responded disagree and strongly disagree,4(22.3\%) answered agree and strongly agree and $2(11.1 \%)$ respondents responded neutral.

According to above data majority of respondents said that assigning disposal committee and their performance was not based on rule and regulations. From the interview made with selected officials' woreda disposal committee were assigned according to rules and regulations but they were not still started disposal activities except collecting properties to be disposed from different sectors of woreda. Observation also proves these properties were collected from different sectors to compound of Woreda Finance and Economic Cooperation office for disposal but still waiting for disposal at place which was not suitable and safe. In addition researcher also observed obsolete and scraps properties which stored for more than 10 years in store of woreda pastoralist development office.

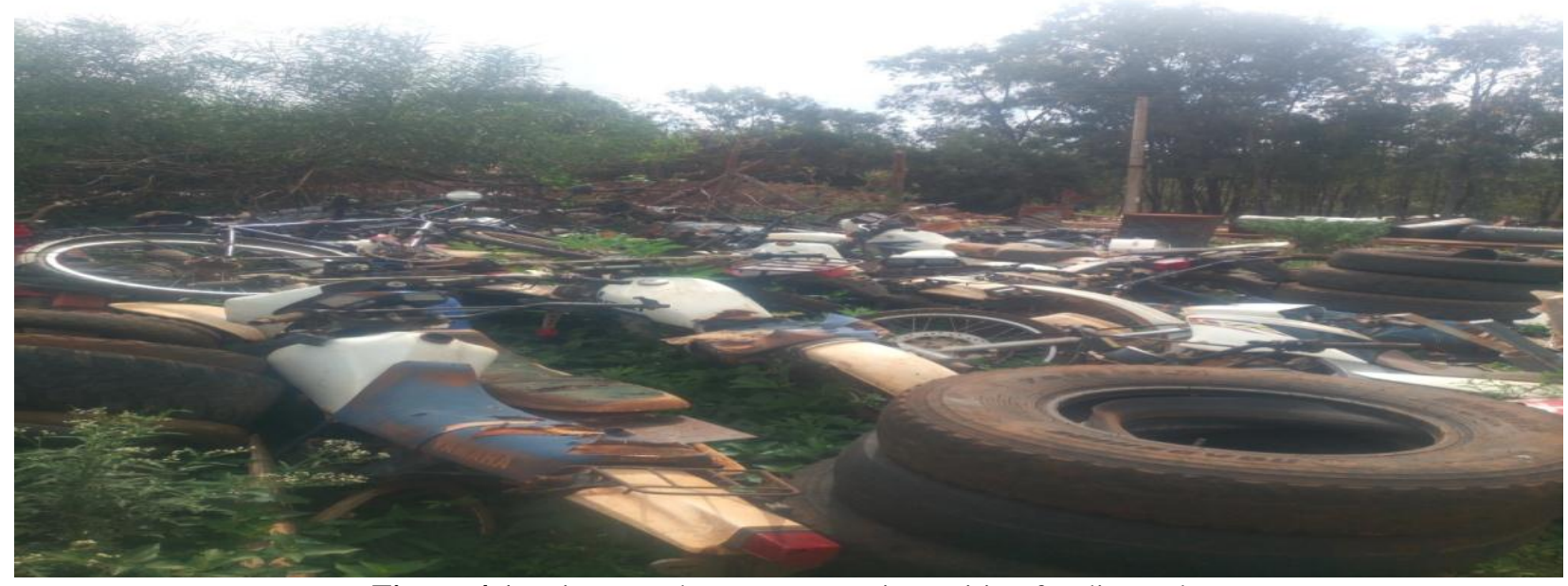

Figure 4.1:-Dire woreda scrap properties waiting for disposal.

Regarding to last item of this table enforcement of law on the process of fixed asset acquisition and management $14(77.8 \%)$ of respondents replied disagree and strongly disagree. A bout $3(16.7 \%)$ respondents were replied agree and $1(5.6 \%)$ respondent responded undecided.

In supporting above data interview made with officials shows the enforcement of law and understanding of existing property administration and disposal rules, regulations and directives was less. In addition to this there is a problem of accountability and follow up according to rules and regulations for damaged property as well as disposing activities was not under taking in this woreda. According to observation made by researcher there was some clues which prove that fixed asset acquisition and management was not undertaking according to rule, regulations and directives.

The below figures shows that fixed asset coding and handling was not undertaking according to directives. In addition researcher observed some fixed asset which is not assigned property identification number (PIN). 


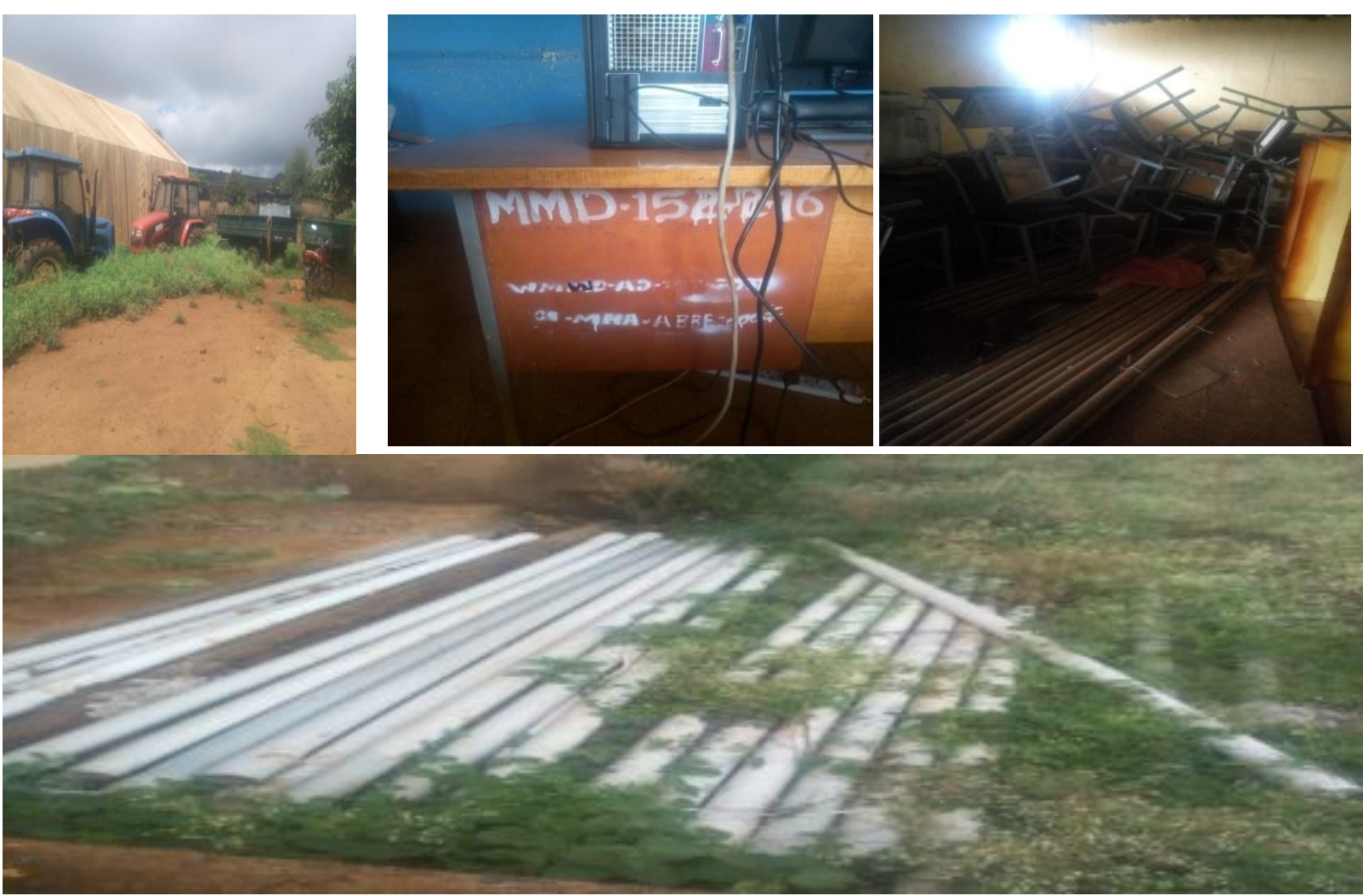

Figure 4.2:-fixed asset miss management in Dire Woreda

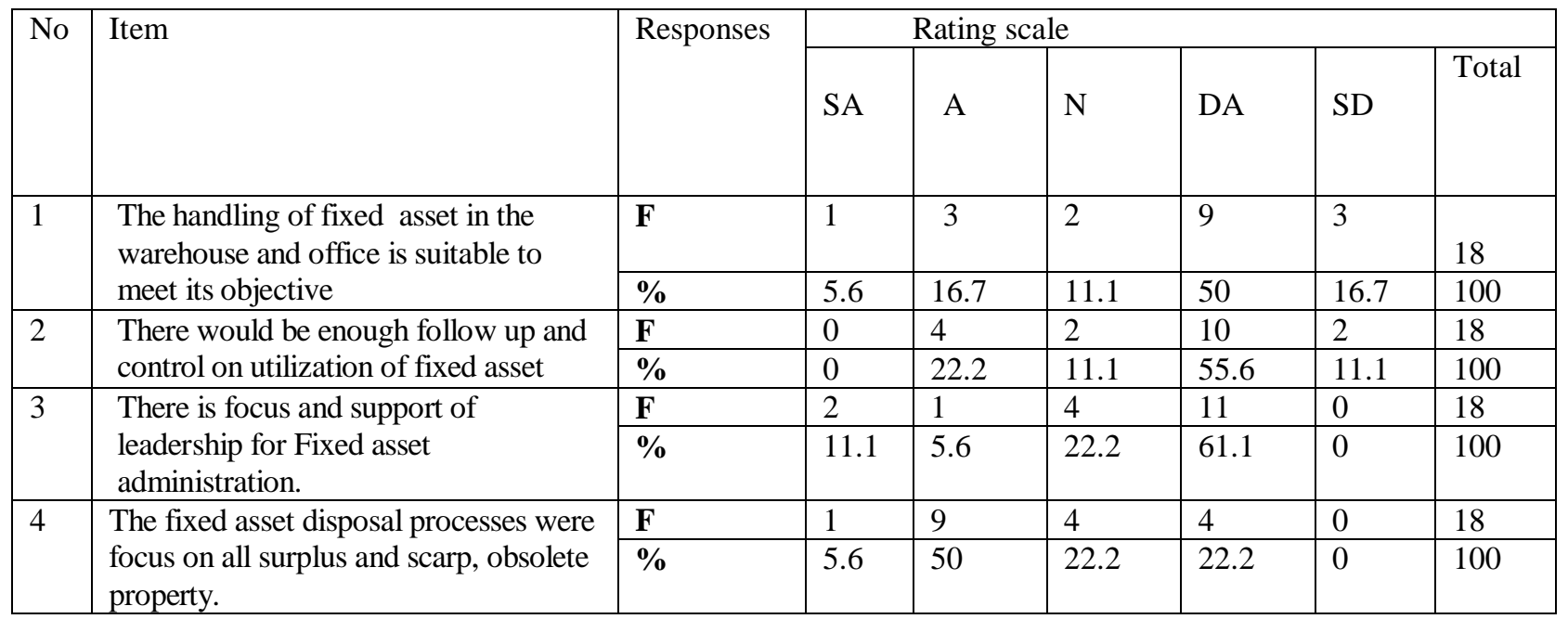

Table 4. 3:-the process of handling and follow up of Dire Woreda fixed asset.

Source: field survey 2019.

From the above table item1 the respondents asked whether the handling of fixed asset in the warehouse and office is suitable to meet its objective. The result revealed that $12(66.7 \%)$ respondents replied disagree and strongly disagree, 4(22.3\%) respondents were agreed and strongly agree and 2(11.1\%) respondents were answered neutral. The observation result shows there were no standard store and the existing by itself not managed properly. Due to this reason all purchased and used fixed asset and non fixed asset were stored at one place. In addition to this properties were stored in every corners of the office of Woreda sectors. 
This implies that there was a poor handling of fixed asset in the woreda public sectors. From above table item 2 the respondents asked whether there would be enough follow up and control on the utilization of fixed asset. As the result majority of respondents, $12(66.7 \%)$ disagree on the idea, 4(22.2\%) respondent agree and $2(11.1 \%)$ respondents were neutral. As shown on the above table item 3 respondents asked regarding focus and support of leadership for fixed asset management but majority of respondents $11(61.1 \%)$ disagree on the idea. While 4(22.2\%) respondent answered neutral and $3(16.7 \%)$ of respondents answered agree. It shows that fixed asset management was not got focus from leadership of the woreda.

From above table item 4 respondents were asked whether asset disposal process focused on all surplus, s carp and obsolete property. The result revealed that $10(55.6 \%)$ respondents were agree and strongly agree, $4(22.2 \%)$ respondents were disagree and the rest $4(22.2 \%)$ of respondents were answered neutral. The interview result made by officials also describe the same idea that even if woreda didn't under take disposal activity till now the process contains all types of properties.

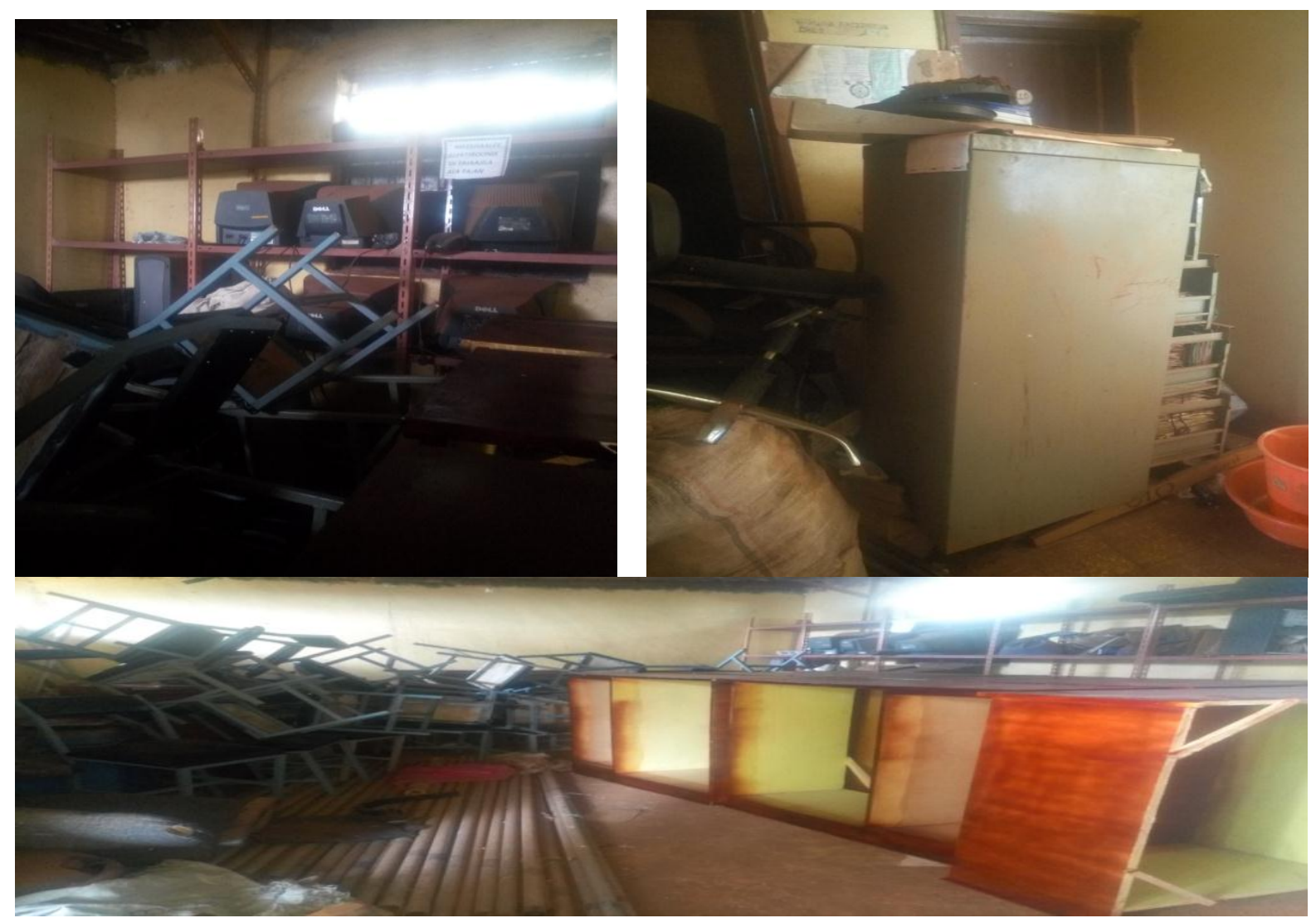

Figure 4.3:-Fixed asset handling in Dire Woreda

The practice of planning process in fixed asset acquisition and management

\begin{tabular}{|c|c|c|c|c|c|c|c|c|}
\hline \multirow[t]{2}{*}{ No } & \multirow[t]{2}{*}{ Items } & \multirow[t]{2}{*}{ Responses } & \multicolumn{4}{|c|}{ Rating scale } & \multirow[b]{2}{*}{ SD } & \multirow[b]{2}{*}{ Total } \\
\hline & & & SA & A & $\mathrm{N}$ & DA & & \\
\hline \multirow[t]{2}{*}{1} & \multirow{2}{*}{$\begin{array}{l}\text { Procurement and distribution of fixed asset } \\
\text { performed based on the demand and needs } \\
\text { from respective sectors }\end{array}$} & $\mathbf{F}$ & 2 & 6 & 3 & 6 & 1 & 18 \\
\hline & & $\%$ & 11.1 & 33.3 & 16.7 & 33.3 & 5.6 & 100 \\
\hline \multirow[t]{2}{*}{2} & \multirow{2}{*}{$\begin{array}{l}\text { The need for fixed asset is raised from } \\
\text { individuals and departments of sectors based } \\
\text { on prepared work plan. }\end{array}$} & $\mathbf{F}$ & 4 & 5 & 1 & 8 & & 18 \\
\hline & & $\%$ & 22.2 & 27.8 & 5.6 & 44.4 & 0 & 100 \\
\hline
\end{tabular}




\begin{tabular}{|l|l|l|l|l|l|l|l|l|}
\hline 3 & $\begin{array}{l}\text { Procurement of fixed asset is based on } \\
\text { specification of the sector. }\end{array}$ & $\mathbf{F}$ & 3 & 7 & 0 & 7 & 1 & 18 \\
\cline { 3 - 9 } & $\mathbf{9}$ & 16.7 & 38.9 & 0 & 38.9 & 5.6 & 100 \\
\hline \multirow{2}{*}{4} & $\begin{array}{l}\text { Property disposal process should be planed } \\
\text { as Formal activity rather than committee } \\
\text { work }\end{array}$ & $\mathbf{F}$ & $\mathbf{6}$ & 5 & 5 & 3 & 2 & 18 \\
\cline { 5 - 10 } & $\mathbf{9}$ & 16.7 & 27.8 & 27.8 & 16.7 & 11.1 & 100 \\
\hline
\end{tabular}

Table 4.4:-Respondents response on practice of planning process in fixed asset acquisition and management Source: field survey 2019

From the above table 4.4 item1 respondents asked whether the procurement and distribution of fixed asset performed based on the demand and needs from respective sectors. As the result $8(44.4 \%)$ of respondents replied agree and strongly agree, $7(38.9 \%)$ of respondents answered disagree and strongly disagree and $3(16.7 \%)$ responded neutral.

Even if majority of the respondents were agree on the idea the second largest response is disagree and strongly disagree on the idea. Interview made with head of Dire finance and economic cooperation office head shows that even though the woreda procured fixed asset based on demand of sectors, shortage of budget to acquire fixed asset according to approved plan, the capacity of sectors to plan right quantity and quality of fixed assets timely was the big problem to procure fixed asset according to plan. So this implies that planning of fixed asset in woreda was relatively in good manner.

A shown in table 4.4 item 2 regarding fixed asset plan $9(50 \%)$ of respondent agree and strongly agree that the need for fixed asset is raised from individuals and departments of sectors based on prepared work plan, 8(44.4\%) of respondent were disagree and strongly disagree and $1(5.6 \%)$ respondent replied neutral. This shows that fixed asset procurement need raised from the respective departments of woreda sectors. From the same table item $310(55.6 \%)$ respondents responded agree and strongly agree, 8(44.5\%) respondents were responded disagree and strongly disagree whether Procurement of fixed asset based on specification of the sector.

Interview made with head of Dire finance and economic cooperation office prove that in woreda procurement of fixed asset was mainly based on sectors specification but the main problem was that sometimes sectors were not specify property to be purchased properly. In the table above item 4 the majority of respondents $8(44.5 \%)$ replied strongly agree and agree, property disposal not to be the committee work it would be formal activity. The less number of respondents $5(27.8 \%)$ replied neutral. The same number of respondents $5(27.8 \%)$ replied disagree and strongly disagree not be formal activity. Interview made with two government officials prove that the main challenge faced them in property disposal activity was that since the work is done by committee it was challenging to be done on time and by commitment.

4.4 Staff professional competency and accountability system in fixed asset acquisition and management Table 4.5:-Respondent's response on staff professional competency

\begin{tabular}{|c|c|c|c|c|c|c|c|c|}
\hline \multirow[t]{2}{*}{ No } & \multirow[t]{2}{*}{ Items } & \multirow[t]{2}{*}{ Responses } & \multicolumn{6}{|c|}{ Rating scale } \\
\hline & & & SA & $\mathrm{A}$ & $\mathrm{N}$ & DA & SD & Total \\
\hline \multirow[t]{2}{*}{1} & \multirow{2}{*}{$\begin{array}{l}\text { The existing property administration } \\
\text { structure would be realizes the } \\
\text { accountability system }\end{array}$} & $\mathbf{F}$ & 2 & 7 & 7 & 2 & 0 & 18 \\
\hline & & $\%$ & 11.1 & 38.9 & 38.9 & 11.1 & 0 & 100 \\
\hline \multirow[t]{2}{*}{2} & \multirow{2}{*}{$\begin{array}{l}\text { The existing property management } \\
\text { department has enough employees for } \\
\text { work }\end{array}$} & $\mathbf{F}$ & 2 & 3 & 3 & 7 & 3 & 18 \\
\hline & & $\%$ & 11.1 & 16.7 & 16.7 & 38.9 & 16.7 & 100 \\
\hline \multirow[t]{2}{*}{3} & \multirow{2}{*}{$\begin{array}{l}\text { The existing property management } \\
\text { department has filled by necessary } \\
\text { professionals }\end{array}$} & $\mathbf{F}$ & 1 & 3 & 3 & 9 & 2 & 18 \\
\hline & & $\%$ & 5.6 & 16.7 & 16.7 & 50 & 11.1 & 100 \\
\hline \multirow[t]{2}{*}{4} & \multirow{2}{*}{$\begin{array}{l}\text { The existing employees of property } \\
\text { management department have enough } \\
\text { work experiences. }\end{array}$} & $\mathbf{F}$ & 1 & 5 & 2 & 8 & 2 & 18 \\
\hline & & $\%$ & 5.6 & 27.8 & 11.1 & 44.4 & 11.1 & 100 \\
\hline \multirow[t]{2}{*}{5} & \multirow{2}{*}{$\begin{array}{l}\text { Property administration department } \\
\text { would have a good }\end{array}$} & $\mathbf{F}$ & 3 & 7 & 0 & 6 & 2 & 18 \\
\hline & & $\%$ & 16.7 & 38.9 & 0 & 33.3 & 11.1 & 100 \\
\hline
\end{tabular}




\begin{tabular}{|l|l|l|l|l|l|l|l|}
\hline & $\begin{array}{l}\text { communication and alignment with other } \\
\text { sectors of woreda }\end{array}$ & & & & & & \\
\hline
\end{tabular}

Source: field survey 2019

From the above table 4.5 item 1, respondents were asked whether the existing property management structure would be realizes accountability system. Result revealed that 9(50\%) respondents agree and strongly agree, $7(38.9 \%)$ responded neutral and $2(11.1 \%)$ respondents disagree on it. This implies that the existing property management structure would be realizing accountability system.

As shown in above table item 2 10(55.5\%) respondents disagree and strongly disagree on the idea whether property management department has enough employees, 5(27.8\%) respondents agree and strongly agree that the existing employees of department were enough for work and 3(16.7\%) respondents were replied neutral. This result shows that the property administration department has no enough employees for work.

The other issue asked in above table was the professionalism of the employees which working in property administration department. The result shows that 11(61.1\%) respondents replied disagree and strongly disagree, 4(22.3\%) replied agree and strongly agree while 3(16.7\%) respondents replied neutral. This result implies that employees assigned in property administration department were not professionally competent. Observation made by researcher proved that most of the employees of the property Administration department were non professionals except few of them which work on procurement posts. The researcher also observed that property administration department of Dire Woreda finance and economic cooperation office was the place where employees which have lower work experience and education level promoted from lower posts in office assigned.

From above table item $410(55.5 \%)$ respondents replied disagree and strongly disagree, 6(33.4\%) respondent replied agree and strongly agree and $2(11.1 \%)$ respondents answered neutral. This result shows that the employees of woreda finance and economic cooperation office which assigned at department of property administration were not acquire related work experience needed. From the above table last item 10(55.6\%) respondents agreed and strongly agree that property administration department would have a good communication and alignment with other sectors of the woreda, While $8(44.4 \%)$ respondents disagree and strongly disagree on the idea.

The above staff professional competence findings were supported by different empirical studies. Challenges in public sector property management in South Africa were lack or shortage of skills and capabilities among property management staff (Brackertz and Kenley, 2002) cited in Mukori (2013). The Bank didn't timely discard assets that are no longer in service there was fixed asset without serial numbered tag because of lack of experienced professionals (Kikron.et al, 2014).

\section{Conclusions:-}

Acquiring fixed assets that are needed for producing products or rendering services is usual for public organizations. Also they own them through gifts, donation, or transfer to support service provision or carry out particular activity. These assets require efficient and effective management throughout their life, including disposal of no longer usable assets, to drive benefit expected from them. For under taking the task of the asset management in efficient and effective way, dedication of all concerned bodies to whole life of property management is crucial Mata M. (2015). The researcher concludes his findings based on the research questions as follow.

\section{Enforcement of rule, regulations and directives}

In accordance with understanding of fixed asset acquisition and management rules, regulations and directives Dire woreda heads of public sectors as well as employees, finding shows that poor understanding of property administrations rules, regulations and directives.On the other hand in relation to establishing system to increasing understanding of employees and heads of public sectors on the fixed asset acquisition and management rules, regulations and directives, the finding reveals that no established system to increase understanding of rule, regulations and directives in Dire woreda. The literature indicate that absent of training regarding fixed asset management has a great impact on the successful accomplishment of a company fixed asset policy and procedure kikron .et al. (2014).

Oromia regional state property administration Directive No 1/2004 E.C indicate on article 54 for property lose erased according to regional finance directive no.5/2003E.C or paid according to market price for negligently lost 
property. According to this research finding in Dire woreda accountability during damage and lose of property negligently would not be applied. To implement asset management policy effectively public sectors require legal frame work and asset management strategy such as property administration proclamations and directives. This is why Oromia Regional State property administration directive no.1/2004 E.C on articles 23 and 25 details of disposal method and the formation of disposal committee.

Regarding this research finding property disposal committee was not performing their duties according to this directive. Article 8 of the EFG procurement and property administration proclamation no.649/2009 ratifies that public bodies should make sure that property is used economically and efficiently. They are also required to ensure property at their disposal is registered and traced, properly handled and looked after and disposed when it is no longer useful.

As shown in the study analysis there was limitation of fixed asset acquisition and management according to rules and regulations in Dire woreda. Material handling can be defined as a function dealing with preparation, placing and positioning of materials to facilitate their movement and storage. Poor material handling may result in delay leading to idling of equipment Getu, (2018).

According to this research finding there is poor handling of fixed assets in Dire woreda. Finding shows that there were no standard store and the existing itself not managed properly. Due to this reasons purchased and used fixed assets were stored mixed. In addition to this fixed assets were stored in every corner and compound of woreda's sectors in condition that inviting it for damage and lose.

The study finding shows that follow up and control on utilization of fixed asset in Dire woreda was poor. Lack of sufficient standard store, properly handling of the existing store, lack of disposing scrap, surplus and obsolete property and poor handling of fixed asset were the indictors of poor follow up and control of public heads and property administration staffs. According to Oromia Regional State proclamation no157/2002 E.C heads of public bodies shall adopt a life time approach to management of public property, ensure that items of public property are recorded as to date, description, quantity and cost from acquisition to the end of their life time, ensure that the custodial responsibility for each fixed asset acquired is assigned primarily to person using such fixed asset and the name of custody are recorded in the register of fixed asset.

In addition to this, proclamation also ratified that the heads of public bodies shall ensure that all public property is used as productively as possible in carrying out the responsibilities of their public bodies establish proper maintenance system for all public property to ensure that it will operate as economically and effectively as possible accordance with directive of the bureau. But as shown in this research finding focus and support of leadership for property administration activity were weak in Dire Woreda.

According to research finding even though disposing activities were not yet under taken in woreda, the precondition work done for disposing activities included all surplus, scrap and obsolete properties.

The practice of planning process in fixed asset acquisition and management

Once the needs have been identified, the procurement department should develop or communicate a plan on how to deliver the service or good required. The plan must be developed in collaboration with the other functions within the organization, so that it is integrated into the organization's strategy and therefore provided for adequately Shaw, (2010) as cited in Roman L., (2017). In order to able to purchase the right good or service, the specifications of what the organizations need must be clear. These specifications are used to communicate to supplier what is needed and what should be supplied. It is therefore important to have clear, precise and accurate specifications Shaw, (2010) as cited in Roman L. (2017).

According to this research finding there were planning procurement of fixed asset according to demands and need of public sectors in Dire woreda. In addition procurement needs were raised from individuals and departments of public sectors. The research finding also shows that the Woreda fixed assets were also procured based on the sectors specifications, but the main problem in specifying fixed asset were lack of capacity and awareness of public sectors to specify fixed asset according to their need. Research finding revealed that property disposal process were planned as formal activity in the Woreda but disposing activity was not yet performed except precondition work in the woreda. 


\section{Staff professional competency and accountability system in fixed asset acquisition and management}

Research finding shows that the existing property management structure would be realizing accountability system since procurement and property administration was restructured together as one work process separating from finance administration work process.

Article 8 of the EFG procurement and property administration proclamation no.649/2009 stipulates that public bodies are responsible to establish procurement and property administration unit with adequate staff. But this research finding reveal that the property administration department of Dire woreda Finance and Economic Cooperation office had no enough employees for work. Research also revealed that the existing employees were not professionally competent as well as most of them have no sufficient experience for work.

Lastly the research finding shows that property administration department would have a good communication and alignment with other sectors of the woreda.

\section{Recommendations}

This section presents appropriate suggestions regarding fixed asset acquisition and management for Dire Woreda. Based on the findings of the study the researcher would like to forward the following recommendations. In order to enforce rule, regulations and directives awareness and understanding of this rule, regulations and directives was crucial. So Dire Woreda should have enhance understanding of heads of public sectors as well as employees by establishing systems such as facilitating training, making available proclamation, directives and manuals by hard copy and soft copy.

Dire Woreda should be maintaining accountability system in property acquisition and management activity for property which was damaged and lost by negligence of individuals. Such individuals should be asked according to Regional government directive and financial law as well as disciplinary measures should be taken as it will be lesson for other individuals who will commit the same act.

The Woreda should fully manage fixed asset based on given rule, regulations and directives.

Dire Woreda should perform the duties of property disposal according to directive based on threshold given for woreda level and report for concerned body for fixed asset which have to dispose by Agency at regional level. To handle safely, effectively and efficiently public property before distribution and disposal the most important thing is storage. In this regard, the researcher recommends that Dire woreda should build standard store and asset yard which can hold used and purchased fixed asset separately, suitable for fixed asset management work and use it properly.

Dire woreda should create awareness for its sectors regarding how to specify fixed asset to be procured by using information technology and engineering professionals. Dire Woreda should recruit sufficient and experienced professional work force based on structure given for property administration department in order to manage its fixed assets in productive way.

\section{Reference:-}

1. Youtai Lu,2011. The dissertation on Public asset management empirical evidence from the state government in the United state s, Florida Atlantic University Boca Reton Florida.

2. UCC, 2012. Fixed asset policy and procedure Ireland.

3. City of Houston Texas, 2005. Fixed asset accounting and management manual.

4. Ethiopia Federal Democratic Republic Proclamation 649/2009, 2009. Proclamation for Procurement and Property Administration.

5. Kikron Tefera et al. 2014. Research Thesis: An assessment of fixed asset management in case of United Bank share company, St.Mary's University.

6. Prof.Emma okoye et al., 2009. Fixed asset management in public sector organization: economic impact on developing country, Federal polytechnic, Oko.

7. Getu Belete, 2018. Practices and challenges of public property management in oromia national regional state: The case of oromia supreme court.

8. Ethiopia Federal Democratic Republic: Ministry of Finance and Economic Cooperation, 2007. Government Owned Fixed Asset Management Manual.

9. Ethiopia federal democratic republic, 2010, ministry of finance and economic development strategic management manual. 
10. Ethiopia Federal Democratic Republic: Ministry of Finance and Economic Cooperation, 2010. Stock Management Manual May.

11. Ethiopia Federal Democratic Republic,(2014/15). Public procurement and property administration agency survey research on sample federal government office.

12. Tadewos Mentta ,2012. Fixed Asset management practice in Ethiopia: Descriptive study on selected Federal public sectors. Lamp Lambert academic publishing, Oxford, Ox, United Kingdom.

13. John, A. et al.2007. Research Methods for Graduate Business and Social Science Students,New Delhi. Vivek Mehra ,for Response Books.

14. Mata Maldaye, 2015.The Disposal practice of material in public sector: the case of selected sub city of Addis Ababa, journal of finance and accounting, vol.9, No1, 2018.

15. Mukori Samuel, 2013. Property Management in the public sector has specific characteristics which differentiates it from the private sector: evidence from an analysis of the South African market, Faculty of Engineering and the Built Environment.

16. Oromia National Regional State Directive 01/2011, 2011. Property Administration Directive.

17. Oromia National Regional State Proclamation 157/20 10, 2010. Proclamation for procurement and property administration.

18. Oromia National Regional State 2016/17, 2016/2017. Bureau of Finance and Economic Cooperation Audit Report.

19. Roman L., 2017. Public procurement practice and challenges in Ethiopia: evidence from selected public organizations, MA thesis in EMB, AAU College of business and economics department of Accounting and finance Addis Ababa, Ethiopia. 